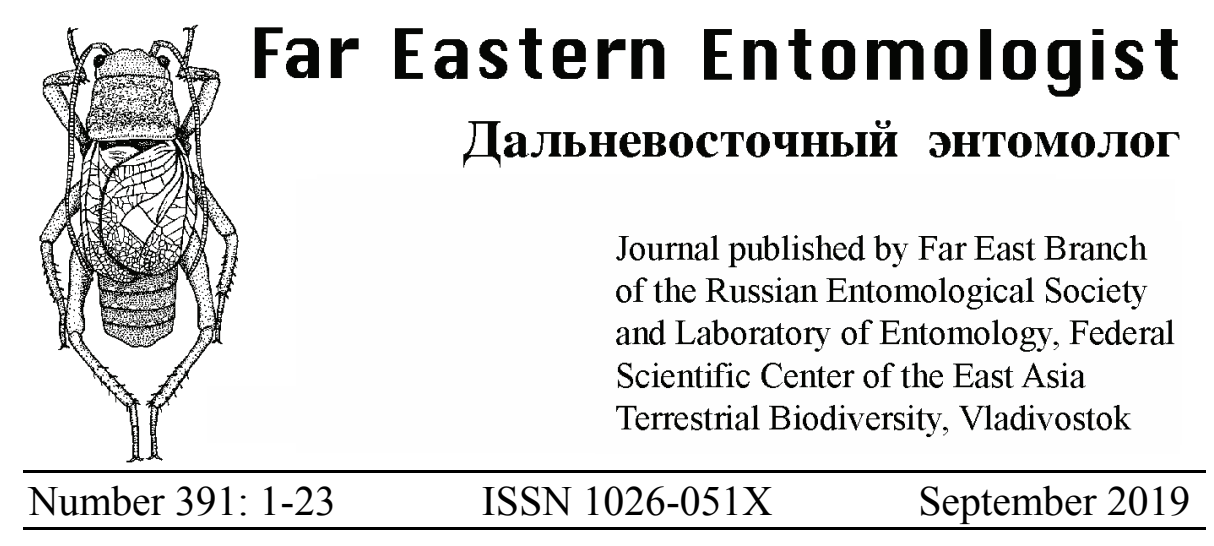

https://doi.org/10.25221/fee.391.1

http://zoobank.org/References/09FA2576-7AA8-42EA-ADFD-D1CD7C5C6600

\title{
NEW DATA ON GEOMETRID MOTHS (LEPIDOPTERA: GEOMETRIDAE) OF THE BAIKAL REGION, RUSSIA
}

\author{
I. A. Makhov ${ }^{1,2)}$, E. A. Beljaev ${ }^{3 *}$ \\ 1) Saint Petersburg State University, Biological Faculty, St. Petersburg 199034, \\ Russia.E-mail: maakhov@mail.ru \\ 2) Zoological Institute of the Russian Academy of Sciences, St. Petersburg \\ 199034, Russia. \\ 3) Federal Scientific Center of the East Asia Terrestrial Biodiversity, Far \\ Eastern Branch of the Russian Academy of Sciences, Vladivostok 690022, Russia. \\ *Corresponding author,E-mail: beljaev@ibss.dvo.ru
}

Summary. The list of 52 species of geometrid moths (Lepidoptera: Geometridae) of the Baikal region (Irkutskaya oblast and Buryatia, Russia) is given. Rheumaptera neocervinalis Inoue, 1982 is reported as new for Siberia, 3 species are new for Baikal region, 18 species are new for Irkutskaya oblast and 4 species are new for Buryatia; distribution in the Baikal region of 4 species is confirmed; literature reference of 23 species from the region are considered as dubious. As result, total number of geometrids in the Baikal region reaches to 347 species from 153 genera. Genus name Scardostrenia Sterneck, 1928, stat. n., is removed from synonymy with the name Proteostrenia Warren, 1895; original combination of the name Scardostrenia reticulata Sterneck, 1928, comb. resurr. is restored. A key to Ourapteryx ussurica Inoue, 1993 and Ourapteryx sambucaria (Linnaeus, 1758) is given. Accuracy of the original geographic labels of the holotypes of Proteostrenia reticulata transbaicalensis Wehrli, 1939, Erannis bajaria var. transbaikalica Wehrli, 1928, and Nothomiza submediostrigata Wehrli, 1939, had been described from Buryatia and Zabaikalsky krai, is discussed. 
Key words: Geometridae, fauna, new records, taxonomy, Irkutskaya oblast, Buryatia, Zabaikalsky krai.

И. А. Махов, Е. А. Беляев. Новые данные о пяденицах (Lepidoptera: Geometridae) Байкальского региона, Россия // Дальневосточный энтомолог. 2019. N 391. С. 1-23.

Резюме. В работе обсуждается 52 вида пядениц (Geometridae) из Байкальского региона (Иркутская область и Бурятия). Из них 1 вид приводится впервые для Сибири (Rheumaptera neocervinalis Inoue, 1982), 3 вида - впервые для Байкальского региона, 18 видов - впервые для Иркутской области и 4 вида впервые для Бурятии; подтверждается обитание в регионе 4 проблемных видов; приведение в литературе для региона 23 видов рассматривается как сомнительное. В результате общее количество пядениц в Байкальском регионе достигло 347 видов из 153 родов. Родовое название Scardostrenia Sterneck, 1928, stat. n., восстановлено из синонимии с Proteostrenia Warren, 1895; восстановлена оригинальная комбинация для названия Scardostrenia reticulata Sterneck, 1928, comb. resurr. Дан ключ для определения бабочек Ourapteryx ussurica Inoue, 1993 и Ourapteryx sambucaria (Linnaeus, 1758). Обсуждается достоверность оригинальных географических этикеток голотипов описанных из Бурятии и Забайкальского края Proteostrenia reticulata transbaicalensis Wehrli, 1939, Erannis bajaria var. transbaikalica Wehrli, 1928 и Nothomiza submediostrigata Wehrli, 1939.

\section{INTRODUCTION}

The Baikal region is a large territory in the central Asia, including the broad environs of Lake Baikal. Two administrative subjects of the Russian Federation are located in the Baikal region: Irkutskaya oblast and Buryatia.

Eversmann, who described 10 new species of geometrids from the vicinity of Irkutsk (Eversmann, 1848, 1851, 1852), was first to start the study these moths in the Baikal region. Thereafter, different authors have published numerous works containing mainly descriptions of solitary new species, or new finds of geometrid moths on the discussed territory. Regarding the most important papers about local or regional Geometridae faunas of the Baikal region, the following publications should be mentioned: Staudinger (1892), Tshugunov (1914), Viidalepp (1974), Vasilyeva \& Epova (1987), Vasilyeva (1989), Mironov (1989), Berlov \& Berlov (2004, 2006), Gordeeva \& Gordeev (2007), and Makhov (2015).

The data on the geometrid fauna of the region published before 2008 as well as original data from various collections were compiled in the corresponding section of the Catalogue of the Lepidoptera of Russia (Mironov et al., 2008). In the Catalogue 245 species of geometrid moths are indicated for Irkutskaya oblast (referred to herein as "Predbaikalsky region") and furthermore 39 species are indicated by question mark as doubtful or putative. Similarly, 293 species and 21 species are indicated for Buryatia (referred to herein as "Pribaikalsky region"). Taking into account the late 
publications (Makhov, 2015, Mironov \& Belova, 2015, Gordeeva, 2016), 260 species of geometrids have been confirmed for Irkutskaya oblast, and 307 species - for Buryatia by now.

The present article provides new materials on the fauna of geometrid moths of Irkutskaya oblast and Buryatia, and clarifies the data on some species listed in the Catalogue of the Lepidoptera of Russia and other previous publications.

\section{MATERIAL AND METHODS}

The basis of this work is a collection of the first author as well as materials from the stock collections of Biological Faculty of Irkutsk State University, Zoological Institute of Russian Academy of Sciences (St. Petersburg) and the personal collection of Eduard Berlov.

The moths sampling was conducted during 9 years (2008-2016) from mid-April to early September with standard methods. The bulk of the geometrids was captured at night (usually since twilight coming to 3-4 am) using a Sylvania HSL-BW 250W E40 mercury lamp powered from a FUBAG TI 1000 petrol generator and a portable screen made of white cotton canvas. The small part of lepidopterans was caught at day-time by an entomological net.

We made the genitalia preparations for externally similar species, and then studied them with a Nikon SMZ 1500 stereomicroscope. The photos of genitalia presented below were performed using a Nikon D700 camera fitted with LV-TV adapter and Helicon software (Helicon Remote 3.8.1; Helicon Focus 6.7.1).

In the annotated checklist given below, species recorded in the federal subject for the first time are indicated as follows: by a single asterisk $(*)-$ new species for Irkutskaya oblast, by double asterisk $(* *)$ - new species for Buryatia, and by triple asterisk $(* * *)$ - new species for whole Baikal region. Each species review contains information on the number of specimens examined, their collecting localities and the date, the collector (if the specimen was not caught by the first author) and deposit location of the material encoded by capital letters in parentheses (namely BF - Biological Faculty of Irkutsk State University, Irkutsk; EB - a personal collection of E. Berlov, Irkutsk; IM - personal collection of I. Makhov, Irkutsk; ZIN - Zoological Institute of Russian Academy of Sciences, St. Petersburg). After the species name the references to the previous mentions of the taxon for the regions are given if present. Distribution in Siberia and Far East is detailed to administrative territories. The taxonomic order is accepted according to the one in an Annotated catalogue of the insects of Russian Far East (Beljaev, 2016).

\section{NEW RECORDS WITH TAXOMOMIC NOTES}

\section{Family Geomrtridae}

Subfamily Ennominae 
Ourapteryx ussurica Inoue, 1993

Figs 1, 8-11

Ourapteryx ussurica: Viidalepp, 1996: 70 ("Buryatia?"); Vasilenko, Gordeeva, 2004: 1438; Gordeeva \& Gordeev, 2007: 134; Berlov \& Berlov, 2006: 107.

Ourapteryx persica (nec Ménétriès, 1832): Vasilyeva, 1989: 113; Vasilyeva \& Epova, 1987: 71.

Ourapteryx sambucaria (nec Linnaeus, 1758): Vasilyeva, 1989: 113; Viidalepp, 1996: 70 ("E. Sayan Mts?"); Mironov \& Belova, 2015.

Ourapteryx koreana Inoue, 1993: Mironov et al. 2008: 193.

MATERIAL. Irkutskaya oblast: Irkutsk distr., Bolshie Koty, $51^{\circ} 54^{\prime} \mathrm{N}, 105^{\circ} 04^{\prime} \mathrm{E}, 11$.VII

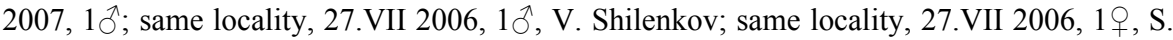
Didorenko); same locality, 12.VII 1965, 10; same locality, 14.VII 1965, 1우 ; same locality, 27.VII 1965, 1今̂, unknown collector); Shelekhovsky distr., $40 \mathrm{~km}$ SW of Irkutsk, Podkamennaya station, $51^{\circ} 57^{\prime} \mathrm{N}, 103^{\circ} 54^{\prime} \mathrm{E}$, 3.VIII 2011, 1ㅇ, V. Shilenkov [BF]; Irkutsk

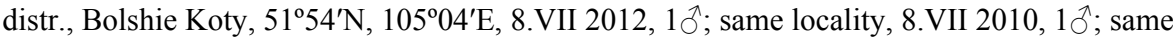

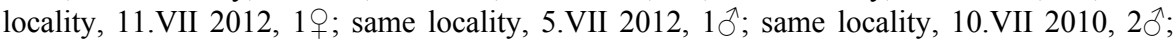

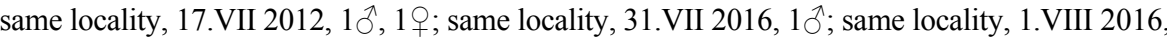

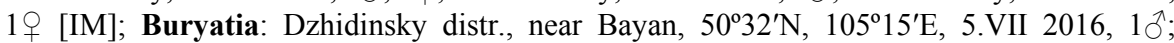
Dzhidinsky distr., $14 \mathrm{~km}$ SE of Petropavlovka settlement, Malyi Tasarkhai base, $50^{\circ} 31^{\prime} \mathrm{N}$,

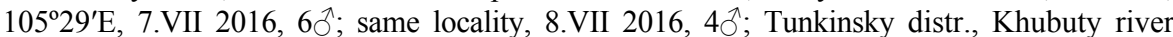
midstream, $35 \mathrm{~km} \mathrm{NW}$ of Kyren, $51^{\circ} 46^{\prime} \mathrm{N}, 101^{\circ} 38^{\prime} \mathrm{E}, 28$.VI $2018,1 \delta^{\Uparrow}$ [IM].

DISTRIBUTION. Russia: S Siberia (S Irkutskaya oblast, Buryatia, Zabaikalsky krai), Far East (Amurskaya oblast, Khabarovsky krai, Primorsky krai); Korea, ?China.

NOTES. Our data confirm the presence in the Baikal region only O. ussurica $(=O$. koreana; the synonymy is established by Beljaev, 2016). The easternmost actual locality for $O$. sambucaria is Cheryomushki village in Krasnoyarsky krai (Zolotuhin, 2017). Due to the difficulty for discrimination of species from $O$. sambucaria - group and potential overlapping of the ranges of $O$. sambucaria and $O$. ussurica in the Southern Siberia, a key to these species is given below.

1. Forewing pointed and distinctly falcate to apex. Straight line drawn along outer margin of hind-wing from its anterior angle to base of tail (wing projection at M3 vein) runs basad of anterior spot on the tail base; longitudinal axes of anterior and posterior spots in base of tail form almost a right angle (Fig. 7). In male genitalia distal process of uncus relatively thick, basal half of calcar (process of juxta) straight; apex of calcar roundedblunted, basal process of aedeagus bent ventrally, cornuti on vesica moderately thin, almost as long as width of aedeagus in middle part. In female genitalia proximal sclerotized portion of corpus bursae is straight

O. sambucaria

- Forewing less pointed and not falcate, outer margin of the wing almost straight. Straight line drawn along outer margin of hind-wing from its anterior angle to base of tail runs through anterior spot on the tail base; longitudinal axes of anterior and posterior spots in base of tail form a wide obtuse angle (Fig. 8). In male genitalia distal process of uncus thin, basal half of calcar smoothly curved; apex of calcar tapered-pointed (beak-shaped), basal process of aedeagus not bent ventrally, cornuti on vesica very thin, much longer than aedeagus width in middle part (Figs 9-11). In female genitalia proximal sclerotized part of corpus bursae is curved

O. ussurica 

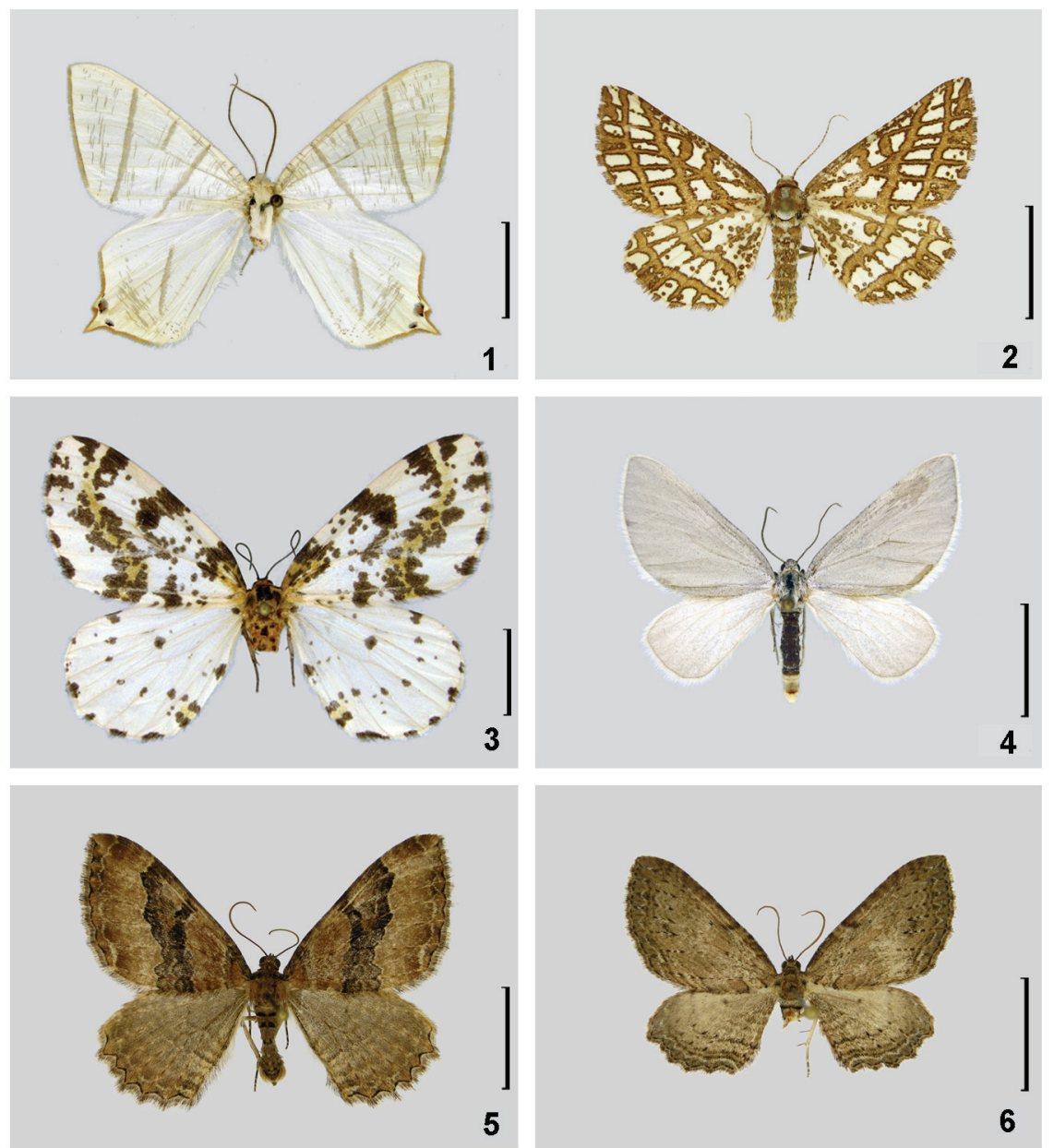

Figs. 1-7. Adilts. 1 - Ourapteryx ussurica Inoue, 1993, male; 2 - Scardostrenia reticulata Sterneck, 1928, female; 3 - Abraxas karafutonis Matsumura, 1925, female; 4 Lithostege farinata (Hufnagel, 1767), male; 5 - Rheumaptera neocervinalis Inoue, 1982, male; 6 - Horisme scotosiata (Guenée, 1858), male.

\section{*Elophos (Yezognophos) vittaria (Thunberg, 1788)}

Elophos vittaria: Mironov et al. 2008: 199 (region 26: "?")

Kemtrognophos remmi (nec Viidalepp, 1988): Berlov \& Berlov, 2006: 108.

MATERIAL. Irkutskaya oblast: Slyudyansky distr., 17 km S of Slyudyanka, Cherskogo

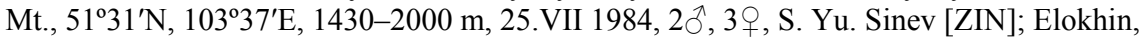
13.VII 2004, 1 , , O. Berlov [EB].

DISTRIBUTION. Russia: N European part (southeast to Udmurtia), Ural, Siberia (YamaloNenets AO, Krasnoyarsky krai, Altai Republic, Tyva, Irkutskaya oblast, Buryatia, Zabaikalsky 
krai, Yakutia), Far East (Magadanskaya oblast); N and Central Europe, ?N Mongolia, Japan (Hokkaido).

NOTES. Here E. vittaria for the first time is correctly indicated for Irkutskaya oblast. The first author revised Eduard Berlov's collection and revealed a female identified as "Kemtrognophos remmi Viid." from the Baikalo-Lensky Nature Reserve (Berlov \& Berlov, 2006) actually is E. vittaria (referred here) and a male "Yezognophos vittaria Thnb." from Buryatia (loc. cit.) (labeled as: "Tunkinsky loaches, near s. Mondy, 1800 m, 27.VI 1974") actually is Charissa turfosaria (Wehrli, 1922).



Figs. 7, 8. Diagnostic characters (indicated) on the wings in Siberian species of Ourapteryx. 7 - Ourapteryx sambucaria (Linnaeus, 1758); 8 -Ourapteryx ussurica Inoue, 1993.

\section{*Diaprepesilla flavomarginaria (Bremer, 1864)}

MATERIAL. Irkutskaya oblast: Irkutsk distr., Bolshie Koty, $51^{\circ} 54^{\prime} \mathrm{N}, 105^{\circ} 04^{\prime} \mathrm{E}, 10$.VII

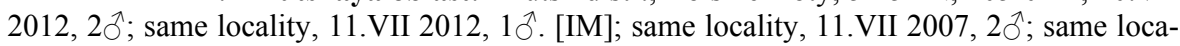
lity, 27.VII 2006, 1§, V. Shilenkov [BF].

DISTRIBUTION. Russia: S Siberia (S Irkutskaya oblast, S Buryatia, SE Zabaikalsky krai), Far East (Amurskaya oblast, Khabarovsky krai, Primorsky krai); N and Central China, Korea.

NOTES. The new locality of $D$. flavomarginaria in Irkutskaya oblast is extreme northwestern in the range of this species.

\section{**Scardostrenia reticulata Sterneck, 1928, comb. resurr.}

Fig. 2

MATERIAL. Buryatia: Dzhidinsky distr., near Bayan, $50^{\circ} 32^{\prime} \mathrm{N}, 105^{\circ} 15^{\prime} \mathrm{E}, 6$.VII 2016 , 29 [IM]

DISTRIBUTION. Russia: S Siberia (Buryatia; ?Zabaikalsky krai); China (Inner Mongolia, Shanxi, Hebei, Beijing, Gansu, Qinghai, Sichuan).

NOTES. Wehrli (1939: 318) placed reticulata in the genus Proteostrenia, in which this species remained up to now, by similar appearance. Nevertheless, the morphology of reticulata does not correspond to Proteostrenia. The systematic position of this species requires an additional research. The reticulata is a type species of the generic name Scardostrenia, and 
provisionally we restore the original combination Scardostrenia reticulata Sterneck, 1928, comb. resurr. Accordingly, the name Scardostrenia Sterneck, 1928, stat. n., is removed from synonymy with the name Proteostrenia Warren, 1895. Taxon Proteostrenia reticulata transbaicalensis Wehrli, 1939, was described based on a single male labeled as "Novorotnaja, Schilka-Fluß, 2000 m, im Juli" [Zabaikalsky krai, 35 km NW of Pokrovka village, $53^{\circ} 30^{\prime} \mathrm{N}, 121^{\circ} 03^{\prime} \mathrm{E}$, Povorotnaya post house, not existing since the end of the 19 th century]. The label content is not correct, as the specified area lacks mountains higher than 1000 meters, and the presence of this southern species in this deeply boreal region on at such heights seems unlikely. Similarly, a holotype of Erannis bajaria var. transbaikalica Wehrli, 1928 possesses the identical label, while the actual finds of Cryopega bajaria ([Denis et Schiffermüller], 1775) are unknown east of Altai. Apparently, in both cases an erroneous labeling took place. Notably, Nothomiza submediostrigata Wehrli, 1939, which holotype is labeled as "Transbaicalien or. mer., Tschikoi-Fluss [Chikoi River], $800 \mathrm{~m}$, Juli", is still known only from the southern provinces of China (Hunan, Guangdong and Hainan). Since the newly discovered locality of $S$. reticulata is nearby the Chikoi River, an erroneous holotype labeling of $N$. submediostrigata by the label actually belonging to the holotype of $P$. reticulata transbaicalensis is not excluded. Differences in appearance between the type specimens of transbaicalensis and nominative reticulata from Sichuan (see Sterneck, 1928: 188, Pl. 4, Fig. 39) are insignificant. Thus, the question on the true type locality and taxonomic status of $P$. reticulata transbaicalensis remains open, but the occurrence of this species in the northeast of Transbaikalia is doubtful.

\section{*Phigalia djakonovi Moltrecht, 1933}

MATERIAL. Irkutskaya oblast: Irkutsk distr., $12 \mathrm{~km} \mathrm{~S}$ of Irkutsk, Lavrentievo noncommercial gardening partnership, $52^{\circ} 08^{\prime} \mathrm{N}, 104^{\circ} 18^{\prime} \mathrm{E}, 24 . \mathrm{IV} 2015,2{ }^{\lambda}$ [IM].

DISTRIBUTION. Russia: SW and S Siberia (Omskaya oblast, Novosibirskaya oblast, Kemerovskaya oblast, Altaisky krai, Altai Republic, Irkutskaya oblast, Zabaikalsky krai), Far East (Amurskaya oblast, Khabarovsky krai, Primorsky krai); NE China, Japan (Hokkaido, Honshu).

NOTES. The find of Ph. djakonovi in Irkutskaya oblast reduces the Baikalian gap in the range of this species.

\section{***Abraxas karafutonis Matsumura, 1925}

Figs 3, 12

MATERIAL. Irkutskaya oblast: Nizhneudinsky distr., $13 \mathrm{~km} \mathrm{~N}$ of Nizhneudinsk,

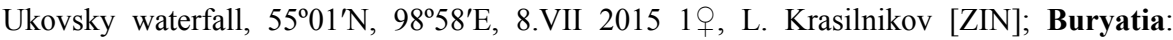
Kabansky distr., $14 \mathrm{~km}$ E of Vydrino, Rechka Vydrinaya, $51^{\circ} 28^{\prime} \mathrm{N}, 104^{\circ} 51^{\prime} \mathrm{E}, 26 . \mathrm{VII} 2014$, 1 $ᄋ$; same locality, 24.VII 2014, 2q; same locality, 19.VII 2014, 1 [ [IM].

DISTRIBUTION. Russia: S Siberia (S Irkutskaya oblast, S and W Buryatia, S Zabaikalsky krai), Far East (Amurskaya oblast, Khabarovsky krai, Primorsky krai, Sakhalin Island); $\mathrm{N}$ Korea, $\mathrm{N}$ and NE China.

NOTES. Specimens A. karafutonis from south of Irkutskaya oblast (Bolshoye Goloustnoye village, Maloe Goloustnoye village) and extreme west of Buryatia (Sagan Shuluta River) from the Rando Müller collection are illustrated on the Lepiforum (Kettner, 2018). Localities of this species near Nizhneudinsk and on Sagan Shuluta River are extreme northwestern in its range. The female genitalia of the species are illustrated for the first time (Fig. 12). 


\section{***Lomaspilis nigrita Heydemann, 1936}

MATERIAL. Irkutskaya oblast: Slyudyansky distr., Snezhnaya River valley, near Vydrino, $51^{\circ} 24^{\prime} \mathrm{N}, 104^{\circ} 38^{\prime} \mathrm{E}, 21 . \mathrm{VI} 2016,10^{\hat{}}$. Buryatia: Kabansky distr., $14 \mathrm{~km}$ E of Vydrino, Rechka Vydrinaya, $51^{\circ} 28^{\prime} \mathrm{N}, 104^{\circ} 51^{\prime} \mathrm{E}, 16 . \mathrm{VII} 2014,1 \widehat{\delta}^{\wedge}$ [IM]

DISTRIBUTION. Russia: European part (N and midland), Ural, W Siberia, S Siberia (Kemerovskaya oblast, Altaisky krai, S Krasnoyarsky krai, Irkutskaya oblast, Buryatia, ?Zabaikalsky krai), Far East (Amurskaya oblast, Khabarovsky krai, Primorsky krai, Sakhalin Island, Kunashir Island); Finland, Baltic countries, Belarus, Poland, Slovakia, Austria, Japan (Hokkaido, Honshu).

NOTES. Due to establishment of L. nigrita as an independent species distinct from $L o$ maspilis opis Butler, 1878 (Beljaev, 2016), indications of the latter for Southern Siberia (Vasilyeva, 1989; Berlov \& Berlov 2006; Gordeeva \& Gordeev, 2007) require a revision. They should be probably attributed to $L$. nigrita.

*Narraga fasciolaria (Hufnagel, 1767)

Narraga fasciolaria: Mironov et al. 2008: 195 (region 26: "?")

MATERIAL. Irkutskaya oblast: Dzhidinsky distr., near Bayanday, $53^{\circ} 01^{\prime} \mathrm{N}, 105^{\circ} 29^{\prime} \mathrm{E}$,

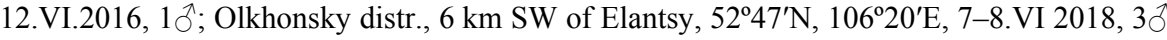
[IM].

DISTRIBUTION. Russia: European part, N Caucasus, Ural, SW Siberia, S Siberia (Altaisky krai, S Krasnoyarsky krai, Altai Republic, Tyva, Irkutskaya oblast, Buryatia, Zabaikalsky krai), Far East (Amurskaya oblast, Khabarovsky krai, Primorsky krai); Central and E Europe, Kazakhstan, NW and N China, Mongolia, Korea.

NOTES. Here $N$. fasciolaria for the first time is reliably given for Irkutskaya oblast. The moths match with nominative subspecies from Europe. The find of this species in Irkutskaya oblast closes the gap in its range.

\section{*Digrammia rippertaria (Duponchel, 1830)}

MATERIAL. Irkutskaya oblast: Olkhonsky distr., $6 \mathrm{~km} \mathrm{SW}$ of Elantsy, $52^{\circ} 47^{\prime} \mathrm{N}$, $106^{\circ} 20^{\prime}$ E, 11.VI 2016, 20; same locality, 7-8.VI 2018, $2 \hat{O}^{\hat{\prime}}$ [IM].

DISTRIBUTION. Russia: S European part, Ural, SW Siberia, S and E Siberia (Altaisky krai, Altai Republic, Tyva, Irkutskaya oblast, Buryatia, Zabaikalsky krai, W and S Yakutia), Far East (Magadanskaya oblast, Amurskaya oblast); S Europe, S Ukraine, Turkey, Kazakhstan, Middle Asia, Mongolia, NW China, N America.

NOTES. The find of D. rippertaria in Irkutskaya oblast closes the gap in the range of this species.

\section{Chiasmia saburraria (Eversmann, 1851)}

Fidonia saburraria Eversmann, 1851: 640.

Chiasmia saburraria: Mironov et al. 2008: 195 (region 26: "?")

MATERIAL. Irkutskaya oblast: Olkhonsky distr., Baikalo-Lensky Nature Reserve, Lake Baikal shore, Cape Bolshoi Solontsovyi, $54^{\circ} 10^{\prime} \mathrm{N}, 108^{\circ} 20^{\prime} \mathrm{E}, 27 . \mathrm{VI}$ 2004, 19 (O. Berlov) [EB]; Cheremkhovsky distr., Malaya Belaya River valley, Pomortseva, $52^{\circ} 49^{\prime} \mathrm{N}$,

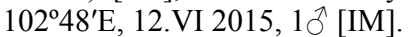

DISTRIBUTION. Russia: S Ural, W Siberia, S Siberia (Altaisky krai, Altai Republic, S Krasnoyarsky krai, Tyva, Irkutskaya oblast, Buryatia, Zabaikalsky krai), Far East (Amurskaya oblast, Primorsky krai); Mongolia, NE China. 
NOTES. Distribution of Ch. saburraria in Irkutskaya oblast is confirmed. The species was described from Irkutsk (Eversmann, 1851), but in Mironov et al. (2008) it was given for the region under the question in view of absence of materials after the description.

\section{SubfamilyGeometrinae}

\section{**Thetidia chlorophyllaria (Hedemann, 1878)}

MATERIAL. Buryatia: Dzhidinsky distr., Lake Nizhnee Beloe, near Beloozyorsk, $50^{\circ} 35^{\prime} \mathrm{N}, 105^{\circ} 45^{\prime} \mathrm{E}$, 3.VII 2016, 1 ; ; Dzhidinsky distr., $14 \mathrm{~km}$ SE of Petropavlovka settlement, Malyi Tasarkhai base, $50^{\circ} 31^{\prime} \mathrm{N}, 105^{\circ} 29^{\prime} \mathrm{E}, 8-9$.VII 2016, $4{ }^{\wedge}$, 1 우 ; same locality, 12 13.VII 2018, 2 + [IM].

DISTRIBUTION. Russia: S Siberia (S Krasnoyarsky krai, S Irkutskaya oblast, Buryatia, Zabaikalsky krai), Far East (Amurskaya oblast, Khabarovsky krai, Primorsky krai); Mongolia, China, Korea.

NOTES. The find of Th. chlorophyllaria in Buryatia closes the gap in the range of this species in Siberia.

\section{Subfamily Larentiinae}

* Lithostege farinata (Hufnagel, 1767)

Figs 4, 13-15

Lithostege onkhoica [sic!]: Berlov \& Berlov, 2006: 106 (nec onchoica Vasilenko \& Gordeeva, 2004).

MATERIAL. Irkutskaya oblast: Cheremkhovsky distr., Malaya Belaya River valley, Pomortseva, $52^{\circ} 49^{\prime} \mathrm{N}, 102^{\circ} 48^{\prime} \mathrm{E}, 12$.VI $2015,1{ }^{\top}, 2$; ; Ekhirit-Bulagatsky distr., near UstOrdynsky, $52^{\circ} 44^{\prime} \mathrm{N}, 104^{\circ} 44^{\prime} \mathrm{E}$, 4.VI 2011, 1 ; ; same locality, 8.VI 2016, 40 ; Irkutsk distr., 5 $\mathrm{km}$ E of Irkutsk, Pilot gardening association, $52^{\circ} 18^{\prime} \mathrm{N}, 104^{\circ} 25^{\prime} \mathrm{E}, 14$.VIII 2009 , 1 \% ; Irkutsk distr., Bolshie Koty, $51^{\circ} 54^{\prime} \mathrm{N}, 1^{\circ} 05^{\circ} 04^{\prime} \mathrm{E}, 4$.VII 2010, 1 ; ; Irkutsk distr., $12 \mathrm{~km}$ S of Irkutsk Lavrentievo non-commercial gardening partnership, $52^{\circ} 08^{\prime} \mathrm{N}, 104^{\circ} 18^{\prime} \mathrm{E}, 19 . \mathrm{VI} 2011,1 \delta^{\top}$; same locality, 19.VI 2012, 3 ; ; Olkhonsky distr., $6 \mathrm{~km} \mathrm{SW}$ of Elantsy, $52^{\circ} 47^{\prime} \mathrm{N}, 106^{\circ} 20^{\prime} \mathrm{E}, 7-$

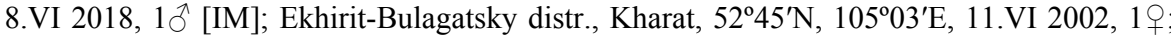
Usolsky distr., Belorechensky, $52^{\circ} 48^{\prime} \mathrm{N}, 103^{\circ} 31^{\prime} \mathrm{E}, 17 . \mathrm{VII}$ 2010, 1 \%; Irkutsk distr., $10 \mathrm{~km} \mathrm{E}$ of Irkutsk, Goloustnensky highway, Fakel gardening association, $52^{\circ} 16^{\prime} \mathrm{N}, 104^{\circ} 31^{\prime} \mathrm{E}, 29 . \mathrm{VI}$ 2006, 1 ${ }^{\top}$; same locality, 30.VI 2002, 1ㅇ, E. Berlov [EB]; Shelekhovsky distr., $40 \mathrm{~km} \mathrm{SW}$ of Irkutsk, Podkamennaya station, $51^{\circ} 57^{\prime} \mathrm{N}, 103^{\circ} 54^{\prime} \mathrm{E}, 26$.VI 2007, 1 우, V. Shilenkov [BF].

DISTRIBUTION. Russia: midland and S European part (midland and S), N Caucasus, Ural, W Siberia, S Siberia (Kemerovskaya oblast, Altaisky krai, Altai Republic, Khakassia, S Irkutskaya oblast, Buryatia); Central, E and SE Europe, ?Turkey, ?Transcaucasus.

NOTES. Formerly L. farinata was reported from "Southern Siberia" (Viidalepp, 1978: 757) and from Khakassia (Korshunov \& Viidalepp, 1982: 105) as subspecies L. farinata bachmutensis Prout, 1938, which was described from the east of Ukraine. The examined specimens from Irkutsk region are close to the Central European L. farinata both in the external features and the genitalia structure.

*Acasis viretata (Hübner, [1799])

MATERIAL. Irkutskaya oblast: Slyudyansky distr., Snezhnaya River valley, near Vyd-

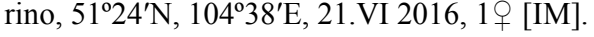


DISTRIBUTION. Russia: European part, N Caucasus, Ural, S Siberia (Novosibirskaya oblast, Altaisky krai, Irkutskaya oblast, Buryatia), Far East (Amurskaya oblast, Khabarovsky krai, Primorsky krai, Sakhalin Island, Kunashir Island); Europe, Transcaucasus, Korea, China, Japan, Northeast India, Nepal, Myanmar.

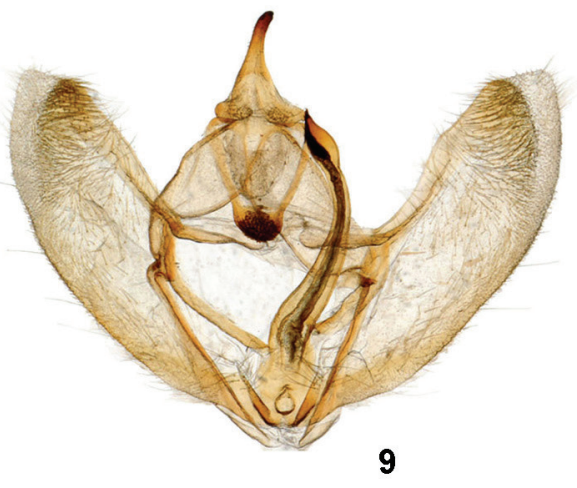

9

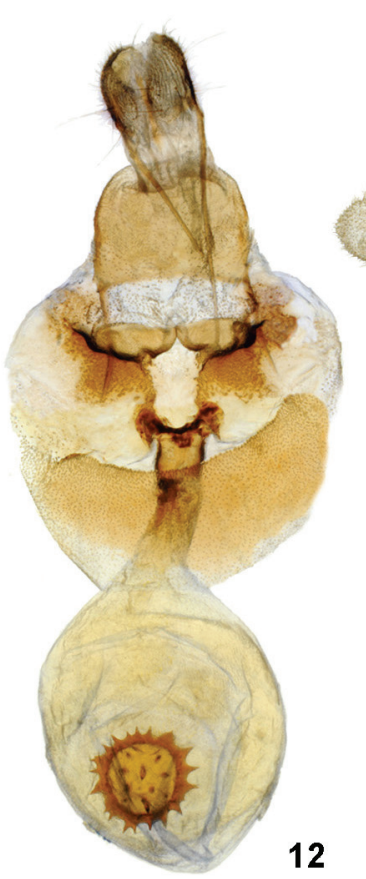

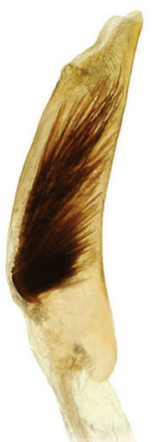

10

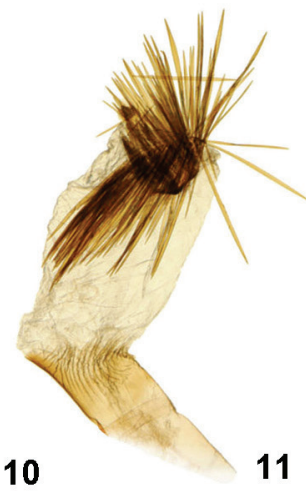

11

Figs. 9-15. The genitalia. 9-11 - Ourapteryx ussurica Inoue, 1993, male genitalia (9ventral view, 10 - fallus, 11 - distal portion of fallus with vesica everted); 12 -Abraxas karafutonis Matsumura, 1925, female genitalia; 13, 14 - Lithostege farinata (Hufnagel, 1767), male genitalia (13 - ventral view, 14 - fallus); 15 - Lithostege farinata (Hufnagel, 1767), female genitalia. 
NOTES. The find of $A$. viretata in Irkutskaya oblast reduces the South Siberian gap in the range of the species.

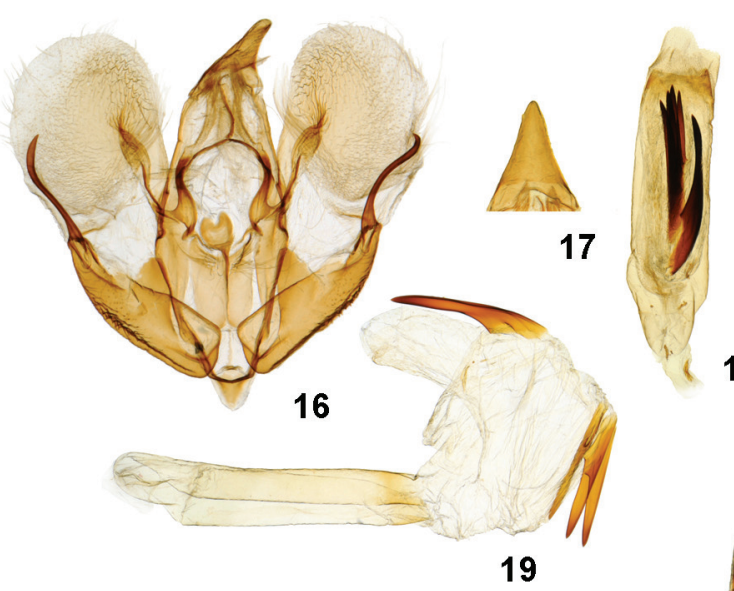

18
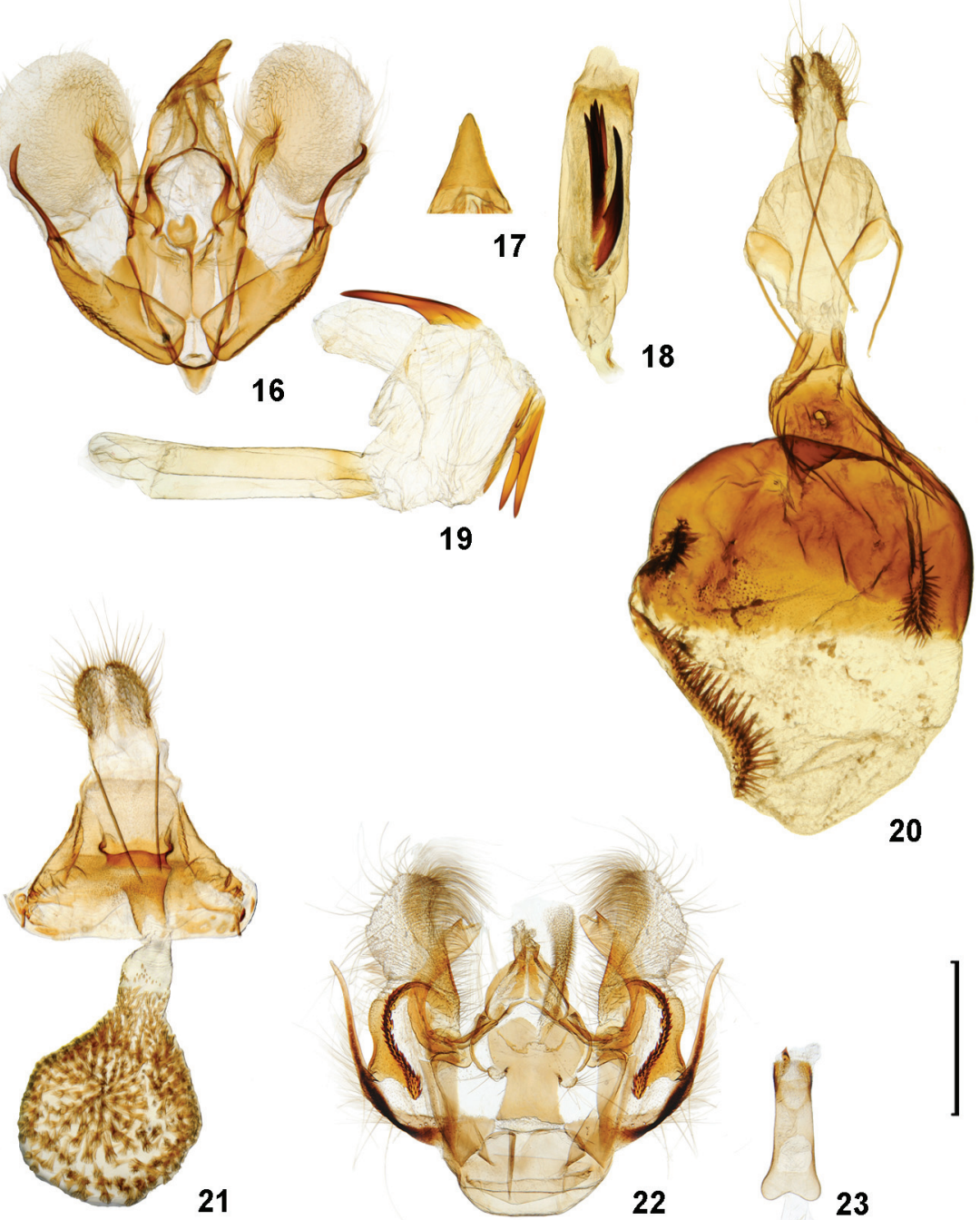

Figs. 16-23. The genitalia. 16-19 - Rheumaptera neocervinalis Inoue, 1982, male genitalia (16 - ventral view, 17 - uncus, 18 - fallus, 19 - fallus with vesica everted); 20 Rheumaptera neocervinalis Inoue, 1982, female genitalia; 21 - Horisme scotosiata (Guenée, 1858), female genitalia; 22, 23 - Horisme scotosiata (Guenée, 1858), male genitalia (22 ventral view, 23 - fallus). 
***Rheumaptera neocervinalis Inoue, 1982

Figs 5, 16-20

Rheumaptera cervinalis (nec Scopoli, 1736): Viidalepp, 1977: 570; Berlov \& Berlov 2006: 105 .

MATERIAL. Irkutskaya oblast: Irkutsk distr., $12 \mathrm{~km} \mathrm{~S}$ of Irkutsk, Lavrentievo noncommercial gardening partnership, $52^{\circ} 08^{\prime} \mathrm{N}, 104^{\circ} 18^{\prime} \mathrm{E}, 11$.VI $2012,10^{\prime}$; same locality, $15 . \mathrm{V}$ 2012, 2ᄋ; same locality, 17.VI 2012, $1 \delta^{\lambda}$; same locality, 1.VI 2013, $1 \delta^{\lambda}$; same locality, $28 . \mathrm{V}$

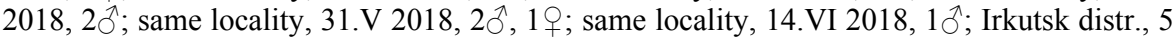


lity, 1.VI 2010, $3 \hat{\circ}$ [IM].

DISTRIBUTION. Russia: S Siberia (S Irkutskaya oblast), Far East (Amurskaya oblast, Khabarovsky krai, Primorsky krai); ?Mongolia (Töw Aimag), Korea, Japan (Hokkaido, Honshu).

NOTES. Rh. cervinalis is reported from Siberia for the first time. The male and female genitalia of Rh. neocervinalis from Irkutskaya oblast (Figs 16-20) are conspecific with those from Primorsky krai, Korea and Japan (Choi, 2013: Figs 73, 124, 175). Previously the species has been wrongly recorded as Rh. cervinalis (Viidalepp, 1977; Berlov \& Berlov 2006). Besides, Viidalepp (1975: 454) listed "Calocalpe cervinalis" for the north of Mongolia (Töw Aimag, $75 \mathrm{~km}$ North of Ulaanbaatar, Noyon Uul, Suzukteh valley) but later he mentioned it as "Hydria hedemannaria" under the question (Viidalepp, 1996: 30 - "Mongolia?"). Beljaev (2016: 625) supposed this reference may belong to $R h$. neocervinalis.

*Perizoma bifaciata (Haworth, 1809)

MATERIAL. Irkutskaya oblast: Irkutsk distr., $12 \mathrm{~km} \mathrm{~S}$ of Irkutsk, Lavrentievo noncommercial gardening partnership, $52^{\circ} 08^{\prime} \mathrm{N}, 104^{\circ} 18^{\prime} \mathrm{E}, 2$.VIII 2011,1 ex.; same locality, 21.VIII 2010, 1 ex.; same locality, 31.VII 2011, 2 ex.; same locality, 6.VIII 2016, 19 [IM]

DISTRIBUTION. Russia: European part, N Caucasus, Ural, SW Siberia, S Siberia (Altaisky krai, Altai Republic, Irkutskaya oblast); Europe, Morocco, Turkey, Cyprus, Transcaucasus, N Kazakhstan, Mongolia (Khovd Aimag), ?Korea.

NOTES. The new locality of $P$. bifaciata is extreme eastern in the range of this species. Actual distribution of this species in Korea from which it was referred recently by single specimen (Tóth et al., 2018) need to be confirmed.

\section{*Chloroclystis v-ata (Haworth, 1809)}

MATERIAL. Irkutskaya oblast: Slyudyansky distr., Snezhnaya River valley, near Vydrino, $51^{\circ} 24^{\prime} \mathrm{N}, 104^{\circ} 38^{\prime} \mathrm{E}, 20$.VI $2016,1 \delta^{\lambda}$ [IM].

DISTRIBUTION. Russia: European part, N Caucasus, Ural, SW Siberia, S Siberia (Altaisky krai, Altai Republic, S Krasnoyarsky krai, Irkutskaya oblast), Far East (Amurskaya oblast, Khabarovsky krai, Primorsky krai, Sakhalin Island, Kunashir Island); Europe, Turkey, Transcaucasus, N Iran, Kazakhstan, Korea, Japan.

NOTES. The find of Ch. v-ata in Irkutskaya oblast somewhat reduces the South Siberian gap in the range of this species.

\section{***Pasiphila debiliata (Hübner, [1817]}

MATERIAL. Irkutskaya oblast: Irkutsk distr., $12 \mathrm{~km} \mathrm{~S}$ of Irkutsk, Lavrentievo noncommercial gardening partnership, $52^{\circ} 08^{\prime} \mathrm{N}, 104^{\circ} 18^{\prime} \mathrm{E}$, 8.VII $2011,1{ }^{\dagger}$; same locality, 15 .VII 2015, 3 ${ }^{\top}$; Kazachinsko-Lensky distr., Kirenga River valley, Konets-Lug, $56^{\circ} 18^{\prime} \mathrm{N}, 1^{\circ} 7^{\circ} 36^{\prime} \mathrm{E}$,

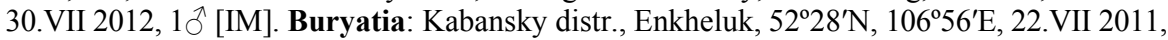


1; Pribaikalsky distr., Selenga River valley, $3 \mathrm{~km} \mathrm{SE}$ of Mostovka, $52^{\circ} 07^{\prime} \mathrm{N}, 107^{\circ} 01^{\prime} \mathrm{E}$, 28.VI 2015, 4 ; Kabansky distr., $14 \mathrm{~km}$ E of Vydrino, Rechka Vydrinaya, $51^{\circ} 28^{\prime} \mathrm{N}$, $104^{\circ} 51^{\prime} \mathrm{E}, 20 . \mathrm{VII} 2014,1$, [IM].

DISTRIBUTION. Russia: European part, ?N Caucasus, Ural, W Siberia, S Siberia (Altaisky krai, Altai Republic, Irkutskaya oblast, Buryatia), Far East (Amurskaya oblast, Khabarovsky krai); Europe, Japan, Korea.

NOTES. The find of $P h$. djakonovi in Irkutskaya oblast and Buryatia reduces the South Siberian gap in the range of this species.

\section{*Eupithecia jezonica Matsumura, 1927}

MATERIAL. Irkutskaya oblast: Olkhonsky distr., Baikalo-Lensky Nature Reserve, Lake Baikal shore, Cape Bolshoi Solontsovyi, $54^{\circ} 10^{\prime} \mathrm{N}, 108^{\circ} 20^{\prime} \mathrm{E}, 31 . \mathrm{VII} 2005$, 1 9 , O. Berlov [EB].

DISTRIBUTION. Russia: SW and S Siberia (Omskaya oblast, Altaisky krai, Altai Republic, Tyva, Irkutskaya oblast, Zabaikalsky krai), Far East (Amurskaya oblast, Khabarovsky krai, Primorsky krai); E Kazakhstan, China, Taiwan Island, Korea, Japan, N India, Nepal.

NOTES. The species was recently discovered in the Omsk region (Knyazev \& Mironov, 2015), where apparently the western border of its range lies.

NOTES. The find of E. jezonica in Irkutskaya oblast reduces the South Siberian gap in the range of this species.

\section{*Eupithecia analoga Djkonov, 1926}

MATERIAL. Buryatia: Pribaikalsky distr., Selenga River valley, $3 \mathrm{~km}$ SE of Mostovka, $52^{\circ} 07^{\prime} \mathrm{N}, 107^{\circ} 01^{\prime} \mathrm{E}, 12$.VIII 2015,1 우 [IM]

DISTRIBUTION. Russia: European part (except south), Ural, W Siberia, S and E Siberia (Irkutskaya oblast, Buryatia, Zabaikalsky krai, S Yakutia), Far East (Sakhalin Island); N, Central and E Europe, Japan (Hokkaido).

NOTES. The find of E. analoga in Irkutskaya oblast closes one of the gaps in the range of this species.

\section{*Eupithecia fennoscandica Knaben, 1849}

MATERIAL. Irkutskaya oblast: Olkhonsky distr., $6 \mathrm{~km} \mathrm{SW}$ of Elantsy, $52^{\circ} 47^{\prime} \mathrm{N}$, $106^{\circ} 20^{\prime} \mathrm{E}, 7-8$.VI 2018, $20^{\lambda}$ [IM]; Olkhonsky distr., $242 \mathrm{~km}$ NE of Irkutsk, Lake Baikal

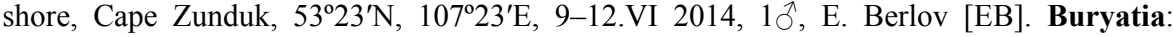
Okinsky distr., Barom-Gol river upstream, $40 \mathrm{~km} \mathrm{NW}$ of Kyren, $51^{\circ} 54^{\prime} \mathrm{N}, 101^{\circ} 37^{\prime} \mathrm{E}$, 20.VI

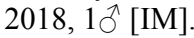

DISTRIBUTION. Russia: N European part, Polar Ural, NW Siberia, S and E Siberia (Altaisky krai, Altai Republic, Irkutskaya oblast, Zabaikalsky krai, S Yakutia), Far East (Magadanskaya oblast); Europe (N Fennoscandia), N Mongolia.

NOTES. The find of E. fennoscandica in Irkutskaya oblast closes one of the gaps in the range of this species.

**Eupithecia dissertata (Püngeler, 1905)

MATERIAL. Buryatia: Okinsky distr., $40 \mathrm{~km}$ W of Orlik, Sentsa River valley, $52^{\circ} 35^{\prime} \mathrm{N}$, 99 ${ }^{\circ} 14^{\prime} \mathrm{E}, 25$.VII 2013, 1 우 [IM].

DISTRIBUTION. Russia: S Siberia (Altai Republic, Tyva, Irkutskaya oblast, Buryatia, Zabaikalsky krai), Far East (Magadanskaya oblast, Khabarovsky krai); Central Europe (mountains), SE Kazakhstan, Mongolia, China (N and Tibet). 
NOTES. The find of E. dissertata in Buryatia closes the South Siberian gap in the range of this species.

*Eupithecia extensaria (Freyer, 1844)

MATERIAL. Irkutskaya oblast: Ekhirit-Bulagatsky distr., near Ust-Ordynsky, $52^{\circ} 44^{\prime} \mathrm{N}$, $104^{\circ} 44^{\prime} \mathrm{E}$, 8.VI 2016, $4{ }^{\Uparrow}$ [IM]

DISTRIBUTION. Russia: European part, N Caucasus, S Ural, W Siberia, S Siberia (S Krasnoyarsky krai, Altaisky krai, Altai Republic, Tyva, Irkutskaya oblast, Buryatia, Zabaikalsky krai), Far East (Amurskaya oblast, Khabarovsky krai, Primorsky krai); Europe, Turkey, Transcaucasus, Kazakhstan, N Kyrgyzstan, Mongolia, NW and N China, Korea, Japan (Hokkaido, Honshu).

NOTES. The find of E. extensaria in Irkutskaya oblast closes the South Siberian gap in the range of this species.

\section{*Eupithecia thalictrata (Püngeler, 1902)}

Eupithecia thalictrata: Mironov et al. 2008: 224 (region 26: "?")

MATERIAL. Irkutskaya oblast: Irkutsk distr., Ushakovka River valley, $10 \mathrm{~km} \mathrm{E}$ of Irkutsk, near Rodnik gardening association, $52^{\circ} 17^{\prime} \mathrm{N}, 1^{\circ} 4^{\circ} 29^{\prime} \mathrm{E}, 13$.VI 2016, 1 \%; Olkhonsky distr., hills in env. of Maloe More, near Chernorud, $53^{\circ} 00^{\prime} \mathrm{N}, 106^{\circ} 49^{\prime} \mathrm{E}, 10$. VI 2016, $10^{\top}$; Olkhonsky distr., $6 \mathrm{~km} \mathrm{SW}$ of Elantsy, $52^{\circ} 47^{\prime} \mathrm{N}, 106^{\circ} 20^{\prime} \mathrm{E}$, 7.VI 2018, 1 \% ; Irkutsk distr., 12 $\mathrm{km} \mathrm{S}$ of Irkutsk, Lavrentievo non-commercial gardening partnership, $52^{\circ} 08^{\prime} \mathrm{N}, 104^{\circ} 18^{\prime} \mathrm{E}$, 15.VI 2018, $1 \delta^{\Uparrow}$ [IM].

DISTRIBUTION. Russia: European part (midland), Ural, SW, S and E Siberia (Omskaya oblast, Altai Republic, Irkutskaya oblast, Zabaikalsky krai, S Yakutia), Far East (Amurskaya oblast, Khabarovsky krai, Primorsky krai, Sakhalin Island, Kunashir Island); Europe (Baltic countries, mountains of Central Europe), North Kazakhstan, North Mongolia, China, Japan (Hokkaido).

NOTES. Here E. thalictrata for the first time is reliably given for Irkutskaya oblast. The find of this species in Irkutskaya oblast reduces the South Siberian the gap in its range.

\section{**Eupithecia millefoliata (Rössler, 1866)}

MATERIAL. Buryatia: Pribaikalsky distr., Selenga River valley, $3 \mathrm{~km}$ NE of Ilyinka,

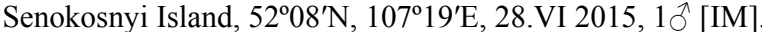

DISTRIBUTION. Russia: European part, N Caucasus, Ural, SW Siberia, S Siberia (Altaisky krai, Altai Republic, Tyva, Irkutskaya oblast, Buryatia); Europe, Morocco, Turkey, Transcaucasus, Kazakhstan, Kyrgyzstan, Uzbekistan, Tajikistan.

NOTES. The new locality of E. millefoliata in Irkutskaya oblast is extreme eastern in the range of this species.

*Horisme scotosiata (Guenée, 1858)

Figs 6, 21-23.

Horisme scotosiata: Mironov et al. 2008: 219 (region 26: "?")

MATERIAL. Irkutskaya oblast: Irkutsk, 4.IX 1970, 10, E. Berlov; Kachugsky distr.,

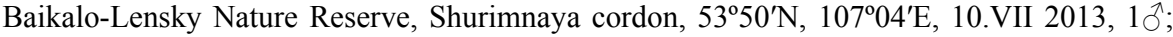
same locality, 10.VIII 2013, 2స, O. Berlov [EB]; Irkutsk, 30.VII 1907, 1 ex., Shchegolkov [BF]; Kazachinsko-Lensky distr., Tukolon landscape reserve, $54^{\circ} 30^{\prime} \mathrm{N}, 107^{\circ} 36^{\prime} \mathrm{E}, 3$.VIII 2014, 1

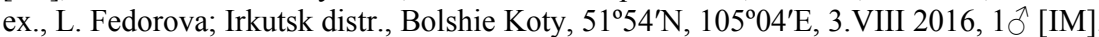


DISTRIBUTION. Russia: S and E Siberia (Kemerovskaya oblast, Altai Republic, S Krasnoyarsky krai, Tyva, Irkutskaya oblast, Buryatia, Zabaikalsky krai, S Yakutia), Far East (Amurskaya oblast, Khabarovsky krai, Primorsky krai, Sakhalin Island); NE Kazakhstan, Mongolia, China (N and Tibet), Korea, Japan.

NOTES. Here H. scotosiata for the first time is reliably given for Irkutskaya oblast. The find of this species closes the gap in its range. The male and female genitalia of this rare species are illustrated (Figs 21-23). By appearance, moths of H. scotosiata can be confused with similar Siberian species, Horisme falcata (Bang-Haas, 1907).

\section{*Anticollix sparsata (Treitschke, 1828)}

MATERIAL. Irkutskaya oblast: Irkutsk distr., $5 \mathrm{~km}$ E of Irkutsk, Pilot gardening association, $52^{\circ} 18^{\prime} \mathrm{N}, 104^{\circ} 25^{\prime} \mathrm{E}$, 23.VI 2010, $10^{\top}$; Slyudyansky distr., Snezhnaya River valley, near Vydrino, $51^{\circ} 24^{\prime} \mathrm{N}, 104^{\circ} 38^{\prime} \mathrm{E}, 21$.VI 2016, $1 \widehat{O}^{\hat{\prime}}$ [IM].

DISTRIBUTION. Russia: European part, Ural, SW Siberia, S Siberia (Altaisky krai, Altai Republic, S Krasnoyarkii krai, Irkutskaya oblast, Buryatia, Zabaikalsky krai), Far East (Khabarovsky krai, Primorsky krai, Sakhalin Island); Europe, Korea, Japan (Hokkaido, Honshu).

NOTES. In addition to the specimens listed above, a photo of $A$. sparsata, taken by E. Bayandina in the vicinity of Irkutsk on July 12.VII 2014, is deposed on the website "Nature of Baikal" (Bayandina, 1014). The find A. sparsata of in Irkutskaya oblast closes the gap in the range of this species.

\section{Subfamily Sterrhinae}

\section{*Scopula virginalis (Fourcroy, 1785)}

Scopula virginalis: Mironov et al. 2008: 209 (region 26: "?")

MATERIAL. Irkutskaya oblast: Irkutsk, 21.VII 2009, 1오. E. Berlov [EB]; Angarsky distr., $20 \mathrm{~km} \mathrm{SW}$ of Angarsk, Galaktika tourist camp, 52 $25^{\prime} \mathrm{N}, 103^{\circ} 37^{\prime} \mathrm{E}, 9 . \mathrm{VIII} 2013$, 1 \%; Irkutsk distr., $12 \mathrm{~km} \mathrm{~S}$ of Irkutsk, Lavrentievo non-commercial gardening partnership, $52^{\circ} 08^{\prime} \mathrm{N}, 104^{\circ} 18^{\prime} \mathrm{E}, 10 . \mathrm{VIII} 2011,1$ ex., 14.VII 2013, 1 ex., 22.VIII 2013, 1 우 [IM]

DISTRIBUTION. Russia: NW European part, Ural, W Siberia, S Siberia (Kemerovskaya oblast, Altaisky krai, Altai Republic, Khakassia, S Irkutskaya oblast, Buryatia, Zabaikalsky krai), Far East (Amurskaya oblast, Khabarovsky krai, Primorsky krai, Kunashir Island); Europe (except S), Central China, Korea, Japan (Hokkaido).

NOTES. Here $S$. virginalis for the first time is reliably given for Irkutskaya oblast. The examined specimens belong to subspecies S. virginalis nivearia (Leech, 1897), which spreads from Ural to Japan (Beljaev, 2016). The find of this species in Irkutskaya oblast closes the South Siberian gap in its range.

\section{*Scopula floslactata (Haworth, 1809)}

Scopula floslactata: Mironov et al. 2008: 208 (region 26: "?")

MATERIAL. Irkutskaya oblast: Olkhonsky distr., Baikalo-Lensky Nature Reserve,

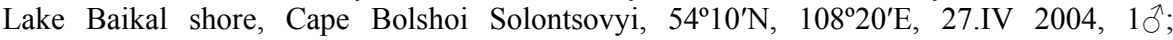
Kachugsky distr., Baikalo-Lensky Nature Reserve, Baikal Range, Isumrudnoe lake, $54^{\circ} 04^{\prime} \mathrm{N}$, $108^{\circ} 10^{\prime} \mathrm{E}, 25$.VI 2004, 1 , , O. Berlov [EB]; Slyudyansky distr., Snezhnaya River valley, near Vydrino, $51^{\circ} 24^{\prime} \mathrm{N}, 104^{\circ} 38^{\prime} \mathrm{E}, 8$.VII 2013, 2 ex., 09.VII 2013, 2 ex., 21.VI 2016, $2{ }^{\star}$; 
Pribaikalsky distr., Selenga River valley, $3 \mathrm{~km}$ SE of Mostovka, $52^{\circ} 07^{\prime} \mathrm{N}, 107^{\circ} 01^{\prime} \mathrm{E}, 24$ 25.VI 2016, 2 ex.; Irkutsk distr., Ushakovka River valley, 10 km E of Irkutsk, near Rodnik gardening association, $52^{\circ} 17^{\prime} \mathrm{N}, 104^{\circ} 29^{\prime} \mathrm{E}$, 13.VI 2016, 1 ex. [IM].

DISTRIBUTION. Russia: European part, Ural, W Siberia, S and E Siberia (Kemerovskaya oblast, Altaisky krai, Altai Republic, S Krasnoyarsky krai, Tyva, Irkutskaya oblast, Buryatia, Zabaikalsky krai, S Yakutia,), Far East (Amurskaya oblast, Khabarovsky krai, Primorsky krai, Sakhalin Island, Kunashir Island); Europe, Mongolia, N and NE China, Korea, Japan.

NOTES. Here $S$. floslactata for the first time is reliably given for Irkutskaya oblast. The find of this species in Irkutskaya oblast closes the South Siberian gap in its range.

\section{Timandra griseata W. Petersen, 1902}

Timandra griseata: Vasilyeva, 1989: 105 (Irkutsk, Turgenevka).

MATERIAL. Irkutskaya oblast: Kazachinsko-Lensky distr., Kirenga River valley, Konets-Lug, $56^{\circ} 18^{\prime} \mathrm{N}, 107^{\circ} 36^{\prime} \mathrm{E}, 29$.VII 2012, $10^{\text {; }}$; Irkutsk distr., $5 \mathrm{~km}$ E of Irkutsk, Pilot gardening association, $52^{\circ} 18^{\prime} \mathrm{N}, 104^{\circ} 25^{\prime} \mathrm{E}$, 7.VII $2008,10^{\top}$; Irkutsk distr., Bolshie Koty, $51^{\circ} 54^{\prime} \mathrm{N}, 105^{\circ} 04^{\prime} \mathrm{E}, 4$.VII 2010, $1 \delta^{\Uparrow}$ [IM]; Irkutsk, 18.VI 2004, 1 ex.; same locality, 10 .VII 2004, $1 \delta^{\top}$; Irkutsk distr., $10 \mathrm{~km} \mathrm{E}$ of Irkutsk, Goloustnensky highway, Fakel gardening association, $52^{\circ} 16^{\prime} \mathrm{N}, 104^{\circ} 31^{\prime} \mathrm{E}, 14$.VII 2006, $1 \delta^{\top}$ (E. Berlov) [EB]; Shelekhovsky distr., 40 $\mathrm{km}$ SW of Irkutsk, Podkamennaya station, $51^{\circ} 57^{\prime} \mathrm{N}, 103^{\circ} 54^{\prime} \mathrm{E}, 10 . \mathrm{VII} 2010$, $10^{\dagger}$; same locality, 16.VII 2011, 1ð, 1 ; ; same locality, 7.VII 2007, 1ठ, V. Shilenkov [BF].

DISTRIBUTION. Russia: N European part, Ural, S and E Siberia (Altaisky krai, Altai Republic, S Krasnoyarsky krai, Irkutskaya oblast, Buryatia, S Yakutia); N Europe.

NOTES. The distribution of the species in Irkutskaya oblast is confirmed. The specimens were verified with DNA barcoding in view the recognition of two sibling species $T$. griseata and Timandra comae A. Schmidt, 1931, by morphology is difficult.

\section{GEOMETRIDAE DUBIOUS FOR THE FAUNA OF THE BAIKAL REGION}

\section{Selenia lunularia (Hubner, 1788)}

Selenia bilunaria Esper, [1801]: Belova, 1988: 21; Belova, 2000: 27.

NOTES. S. lunularia is not known east of Altai. Judging from the same collecting date "Juli 1982", later the species was redetermined as Selenia dentaria (Fabricius, 1775) (Mironov \& Belova, 2015).

\section{Ennomos quercinaria (Hufnagel, 1767)}

Ennomos quercinaria: Vasilyeva, 1989: 112;

NOTES. The species is not known east of the S Ural.

\section{Ourapteryx persica (Ménétriès, 1832)}

Ourapteryx persica: Vasilyeva \& Epova, 1987: 71.

NOTES. Distribution of this species is limited to E Transcaucasia and N Iran.

Ourapteryx sambucaria (Linnaeus, 1758)

Ourapteryx sambucaria: Mironov \& Belova, 2015: 60.

NOTES. Judging from the same collecting date "15.07.1992", the species was redetermined as Ourapteryx ussurica Inoue, 1993 (Belova, 2015). 
Pungeleria capreolaria ([Denis et Schiffermüller], 1775)

Pungeleria capreolaria: Vasilyeva, 1989: 112;

NOTES. The species is not known east of the Carpathians and Turkey.

\section{Erannis defoliaria (Clerck, 1759)}

Erannis defoliaria: Belova, 1986: 88; Belova, 2013: 190.

NOTES. The species is not known east of the Urals. N.A. Belova notes E. defoliaria from the Baikal Reserve in a number of publications from with the first and last ones are cited above. Obviously, later this species was redetermined as Erannis jacobsoni (Djakonov, 1926) (Mironov \& Belova, 2015).

\section{Biston strataria (Hufnagel, 1767)}

Biston stratarius: Vasilyeva, 1989: 112.

NOTES. The species is not known east of the south of Krasnoyarsky krai. Distribution of the species in the Baikal region is not excluded, but has to be confirmed.

\section{Peribatodes rhomboidaria ([Denis et Schiffermüller], 1775)}

Peribatodes rhomboidaria: Vasilyeva, 1989: 111.

NOTES. The species is not known east of the South Ural.

\section{Isturgia roraria (Fabricius, [1776])}

Isturgia roraria: Belova, 2003: 88; Belova, 2009: 154.

NOTES. The species is not known east of the South Ural.

\section{Cataclysme riguata (Hübner, [1813])}

Cataclysme riguata: Belova, 2005: 272.

NOTES. The species is not known east of Altai.

\section{Xanthorhoe annotinata (Zetterstedt, 1839)}

Xanthorhoe annotinata: Vasilyeva, 1989: 107.

NOTES. The species is not known east of north-east of European part of Russia; another species from the $X$. annotinata species group are distributed in the Baikal region.

\section{Epirrhoe molluginata (Hübner, 1813)}

Cidaria molluginata Belova, 1986: 87; Belova, 1988: 20.

Epirrhoe molluginata: Belova, 2000: 25; Belova, 2009: 153.

NOTES. The species is not known east of middle Volga.

\section{Epirrhoe galiata ([Denis et Schiffermüller], 1775)}

Epirrhoe galiata: Vasilyeva, 1989: 107.

NOTES. The species is not known east of the Urals. 


\section{Pennithera firmata (Hübner, [1822])}

Thera firmata: Belova, 2005: 272.

NOTES. The species is not known east of the S Ural. Judging from the same collecting date "25.07.[20]01", later the species was redetermined as Thera obeliscata (Hübner, [1787]) (Mironov \& Belova, 2015).

\section{Thera cognata (Thunberg, 1792)}

Thera cognata: Belova, 2000: 26; Belova, 2003: 87; Belova, 2008: 46.

NOTES. Nearest localities of Th. cognata are known from the west of European part of Russia and form Caucasus.

\section{Eupithecia impurata (Hübner, 1813)}

Eupithecia impurata: Belova, 2000: 26; 2003: 87.

NOTES. Central European species which is unknown east of Carpathians.

\section{Eupithecia irriguata (Hübner, [1813])}

Eupithecia irriguata: Belova, 2003: 89.

NOTES. Nearest localities of E. irriguata are known from Caucasus.

\section{Horisme intricata (Staudinger, 1882)}

Horisme intricata: Belova, 2005: 272.

NOTES. The wrong definition of the specimen of Horisme incurvaria (Erschoff, 1877), which photo is published on the site "1000 Siberian Butterflies and Moths" (Berlov \& Berlov, 1999-2014).

\section{Idaea deversaria (Herrich-Schäffer, 1847)}

"S[copula] deserticola H.-S.": Belova, 2000: 25;

Sterrha deversaria: Belova, 2003: 88.

NOTES. The species is not known east of the Urals. Probably, the "S. deserticola H.-S." (Belova, 2000) is erroneous spelling of the "Sterrha deversaria H.-S." (Belova, 2003).

\section{Idaea ochrata (Scopoli, 1763)}

Sterra ochrata: Belova, 2005: 272.

NOTES. The species is not known east of the S Urals.

\section{Idaea seriata (Schrank, 1802)}

Sterrha seriata: Vasilyeva, 1989: 105.

NOTES. The species is not known east of the Volga region.

\section{Idaea serpentata (Hufnagel, 1767)}

Idaea serpentata: Berlov \& Berlov, 2006: 102; Belova, 2012: 42; Belova, 2015: 220; Mironov \& Belova, 2015: 61. 
NOTES. The two vicarious species, West Palaearctic $I$. serpentata and East Palaearctic $I$. dohlmanni, are almost identical on appearance and definitely distinguishable only by the genitalic structure, that results to numerous misidentification of the last species as first one (Viidalepp, 1987; Burnasheva, Beljaev, 2011). All studied specimens of "I. serpentata" from Irkutskaya oblast, deposited in the collections of Zoological Institute (materials by I. Kozhanchikov $-3 \hat{\jmath} \widehat{\partial}$, and S. Rodionov $-2 \hat{\jmath})$ ), Biological Faculty of Irkutsk State University $(11 \hat{\jmath})$ and Siberian Institute of Plant Physiology and Biochemistry $(8 \hat{\jmath})$ actually belong to I. dohlmanni. No samples of I. serpentata were also detected in the author's materials from Baikal region $(11 \hat{\partial}, 1$ ) $)$. Thus, the eastern range limit of $I$. serpentata is presumably laid to the west of the Baikal region.

\section{Cyclophora pendularia (Clerck, 1759)}

? Ephyra pendularia: Tshugunov, 1914: 316

Cosymbia pendularia: Djakonov, 1926: 22; Viidalepp, 1979: 88; Korshunov \& Viidalepp, 1980: 46; Belova, 1986: 88.

Cyclophora pendularia: Belova, 1988: 19; Vasilyeva, 1989: 105; Mironov et al., 2008: 210 (the regions 22-25, 27); Mironov \& Belova, 2015: 61.

NOTES. Actually true $C$. pendularia is not known east of the West Siberian Plain. All records of "Cyclophora pendularia" or "Cosymbia pendularia" east of the region are evidently based on the Geometra pendularia sensu [Denis \& Schiffermüller], 1775 (nec Clerck, 1759), which is misidentification of Cyclophora albipunctata (Hufnagel, 1767). The long time of history of this misidentification results to numerous misunderstanding. In the referring list above the references containing materials are given only (excepting the Mironov et al., 2008). Among the publications of N.A. Belova with indication of the "C. pendularia" in the Baikal Reserve only first and last ones are cited here.

\section{CONCLUSION}

As a result of this research 1 species (Rh. neocervinalis) was recorded in Siberia for the first time, 3 species was reported as new for the Baikal region, 18 species as new for Irkutskaya oblast and 4 species - as new for Buryatia; distribution in the Baikal region of 4 species is confirmed. For five species of geometrid moths, the range limits are significantly extended: the eastern boundary is expanded for $P$. bifaciata and E. millefoliata, and the western one - for D. flavomarginaria, $A$. karafutonis and Rh. neocervinalis. In addition, the literature's referring of 23 species from region are quite dubious and we propose to exclude them from the fauna of the Baikal region up to confirmation. Following the new data, in the Baikal region the family Geometridae currently numbers 347 species from 153 genera and 5 subfamilies. The exploration degree of the species richness of geometrid moths in the region is estimated to be close to $90 \%$.

\section{ACKNOWLEDGMENTS}

The financial support for work of the first author was provided by the grants of Russian Foundation for Basic Research № 18-04-00263a (field trips, collecting the 
material) and Russian Science Foundation № 14-14-00541 (analysis of the material).The first author expresses his gratitude to Eduard Berlov (Irkutsk) for providing the materials from his personal collection, to Maria Dementeva (Biological faculty, Irkutsk State University, Irkutsk) for being great company and assistance during the field investigations. The authors express a special gratefulness to Alexey Matov (ZIN, St. Petersburg) for giving an opportunity to use his personal photographic equipment. The second author thanks Sergey Vasilenko (Institute of Systematic and Ecology of Animals, Siberian Branch of Russian Academy of Sciences, Novosibirsk) for a number of valuable consultations. Performing the work of the second author was sponsored partially by Russian Foundation for Basic Research, project 18-0400944.

\section{REFERENCES}

Bayandina, E. 1014. Fotootchet "Babochki-2014". Anticollix sparsata. In: V. Petukhin (Ed.). "Nature of Baikal" website (accessed October 2, 2018). http://nature.baikal.ru/ obj.shtml?obj=fauna\&id=anticollix sparsata

Beljaev, E. A. 2016. Fam. Geometridae - Pyadenitzi. P. 518-666. In: A. S. Lelei (Ed.), Annotated catalogue of the insects of Russian Far East. Vol. 2. Lepidoptera. Dalnauka, Vladivostok. [In Russian]

Belova, N.A. 1986. Higher heterocerous lepidopterans (Heterocera, Macrolepidoptera) of the Baikal Reserve. P. 83-98. In: Amirkhanov A.M. (Ed.). Fauna and ecology of invertebrates in the natural reserves of the RSFSR. Moscow. [In Russian]

Belova, N.A. 1988. Higher hererocerous Lepidoptera: an annotated list of species. P. 5-23. In: Sokolov B.E. (Ed.) Flora and Fauna of the USSR Nature Reserves. Fauna of the Baikal Reserve: operational information material. Moscow. [In Russian]

Belova, N.A. 2000. Taxonomic list of the highest hererocerous Lepidoptera of the reserve "Baikalsky". P. 23-36. In: Materials of research of natural complexes of the Southern Baikal region. Proceeding of the State natural biosphere reserve "Baikalsky". Ulan-Ude. [In Russian]

Belova, N.A. 2003. The dynamics of the species diversity of higher heterocerous lepidopterans in the Baikal Reserve. P. 85-91. In: Boichenko V.S. (Ed.) Study and monitoring of protected natural complexes. Proceedings of the Baikal State Natural Biosphere Reserve. Issue 3. Ulan-Ude. [In Russian]

Belova, N.A. 2005. To the fauna of the higher heterocerous lepidopterans (Heterocera: Macrolepidoptera) of the Baikal Reserve. P. 272-273. In: Mountain systems of Southern Siberia: study, conservation and environmental management. Proceedings of the Tigirek Natural Reserve. Vol. 1. Barnaul. [In Russian]

Belova, N.A. 2008. To the fauna and ecology of moths of the Southern Baikal region (2007). P. 45-47. In: Nature of Baikal Siberia. Proceedings of nature reserves and national parks of Baikal Siberia. Issue 1. Ulan-Ude. [In Russian]

Belova, N.A. 2009. To the fauna and ecology of geometrid moths of the Southern Baikal region (2008). P. 152-154. In: Gudina A.N. (Ed.) Biodiversity and the role of specially protected natural sites in its conservation. Materials of the international scientific conference, dedicated to the 15th anniversary of the State Natural Reserve "Voroninsky". Tambov. [In Russian] 
Belova, N.A. 2012. To the fauna of the higher heterocerous lepidopterans (Heterocera, Macrolepidoptera) of the Southern Baikal [Original translation is: "About the fauna Heterocera, Macrolepidoptera austral Prebaikalia (2001-2011)"]. P. 41-43. In: Ecology, evolution and systematics of animals. Materials of International scientific and practical conference. Golos Gubernii, Ryazan. [In Russian]

Belova, N.A. 2013. To the fauna and ecology of geometrids of the Southern Baikal region (2012). P. 186-190. In: Study, preservation and restoration of natural landscapes. A collection of articles of 3-rd international scientific-practical conference (October 0710, 1913, Volgograd). Planeta, Moskow. [In Russian]

Belova, N.A. 2015. Rare species of higher heterocerous lepidopterans (Lepidoptera Metaheterocera) of the Baikal Reserve [Original translation is: "Rare types of moths (Lepidoptera Metaheterocera) of Baikal strict Nature Reserve"]. P. 219-224. In: Davydov E.A. (Ed.) Mountain ecosystems of South Siberia: study, conservation and rational nature use. Proceedings of the Tigirek Natural Reserve. Vol. 7. Barnaul. [In Russian]

Berlov, E. \& Berlov, O. 1999-2014. Horisme ?intricata (Staudinger, 1882). 1000 Siberian Butterflies and Moths. CD-ROM and Web-Site (accessed Oktober 2, 2018). http:// catocala.narod.ru/geom74i.html

Berlov, E.Ya. \& Berlov, O.E. 2004. New and interesting lepidoptera (Insecta, Lepidoptera) in the Baikal region. Bulletin of the Irkutsk State Agricultural Academy, 25: 67-71. [In Russian]

Berlov, O.E. \& Berlov, E.Ya. 2006. Materials for the fauna and ecology of moths (Lepidoptera, Geometridae) of the Baikal region. Proceedings of the State Nature Reserve "Baikalo-Lensky", 4: 102-110. [In Russian]

Burnasheva, A.P. \& Beljaev E.A. 2011. New data on the fauna of geometrid moths (Lepidoptera, Geometridae) of Yakutia. I. Proceedings of the Russian Entomological Society, 82: 57-66. [In Russian with English Summary].

Choi, S.-W. Geometrids. 2013. Insect fauna of Korea. Vol. 16, No. 10. Arthropoda: Insecta: Lepidoptera: Geometridae 3. Incheon: National Institute of Biological Resources. 109 pp.

Djakonov, A. M. 1926. Zur Kenntnis der Geometriden fauna des Minussinsk Bezirks (Sibirien, Jenissej Gouv.). Jahrbuch des Martjanov'schen Staatsmuseums in Minussinsk (Sibirien), 4(1): 1-78. [In Russian and German].

Eversmann, E. 1848. Beschreibung einiger neuen Falter Russlands. Bulletin de la Société Impériale des Naturalistes de Moscou, 21(3): 205-232.

Eversmann, E. 1851. Description de quelques nouvelles espèces de Lépidoptères de la Russie. Bulletin de la Société Impériale des Naturalistes de Moscou, 24 (4): 610-644.

Eversmann, E. 1852. Mittheillung uber eniger Falter Russlands. Bulletin de la Société Impériale des Naturalistes de Moscou, 25(1): 148-169.

Gordeeva T.V. 2016. To the fauna of moths (Lepidoptera, Geometridae) of Buryatia . Bulletin of Buryat State University, 1: 47-50. [In Russian with English Summary]

Gordeeva, T.V. \& Gordeev, S.Yu. 2007. Family Geometridae - pyadenitzy. P. 95-148. In: Ubugunova, L.L. \& V.V. Dubatolov V.V. (Eds). Lepidoptera of Buryatia. Siberian Branch of the Russian Academy of Sciences, Novosibirsk. [In Russian]

Kettner, M. 2018. Abraxas karafutonis Matsumura, 1925. Lepiforum. Bestimmungshilfe für die in Europa nachgewiesenen Schmetterlingsarten (accessed 2 Oktober 2018). http:// www.lepiforum.de/lepiwiki.pl?Abraxas_Karafutonis

Knyazev, S.A. \& Mironov, V.G. 2015. New species of the pugs (Lepidoptera, Geometridae: Eupithecia) for Southern part of West Siberia, Russia. Eurasian Entomological Journal, 14: 139-141. [In Russian with English Summary] 
Korshunov, Yu.P. \& Viidalepp, J.R. 1980. Pyadenitzy (Lepidoptera, Geometridae) of Khakassia. Communication 1. P. 44-51. In: Zoliotarenko G.S. (Ed.). The fauna and ecology of herbivorous and predatory insects of Siberia. Proceedings of the Biological Institute, Issue 43. Nauka, Novosibirsk. [In Russian]

Korshunov, Yu.P. \& Viidalepp, J.R. 1982. Geometrid moths (Lepidoptera, Geometridae) of Khakassia. Report 2. P. 101-103. In: Beneficial and Harmful Insects of Siberia. Nauka, Novosibirsk. [In Russian]

Makhov, I.A. 2015. Eupithecia Curtis, 1825 (Geometridae, Larentiinae) of Southern Baikal Siberia. Eurasian Entomological Journal, 14: 149-156. [In Russian with English Summary]

Mironov, V.G. \& Belova, N.A. 2015. To fauna and ecology of moths (Lepidoptera: Thyatiridae, Drepanidae, Geometridae) of Baikal lake shore of Baikal nature reserve. Amurian Zoological Journal, 7(1): 58-64. [In Russian with English Summary]

Mironov, V.G. 1989. Eupithecia (Lepidoptera, Geometridae) from Southern Siberia, with description of a new species. Annales entomologici Fennici, 55: 145-152.

Mironov, V.G., Beljaev, E.A. \& Vasilenko, S.V. Sem. Geometridae. P. 190-227. In: Sinev S.Y. (Ed.). Catalogue of the Lepidoptera of Russia. KMK Scientific Press Ltd., St. Petersburg-Moscow. [In Russian]

Staudinger, O. 1892. Lepidopteren des Kentei-Gebirge. Deutsche entomologische Zeitschrift Iris, 5: 300-394.

Sterneck, J. 1928. Die Schmetterlinge der Stötznerschen Ausbeute. Geometridae, Spanner. Deutsche Entomologische Zeitschrift Iris, 42: 131-244.

Tóth, B., Katona, G. \& Bálint, Z. 2018. Data of Geometridae (Lepidoptera) from the Korean Peninsula in the collections of the Hungarian Natural History Museum - subfamily Larentiinae. Folia Entomologica Hungarica, 79: 127-161.

Tshugunov, S. 1914. Les Lépidoptères recueillis pres de la station " Zima" du Transsibérien (Gouvernement d'Irkutsk, district Balagansk). Revue Russe d'Entomologie, 14 (2-3): 307-318. [In Russian]

Vasilenko, S.V. \& Gordeeva (Vlasova) T.V. 2004. New species and interesting finds of geometrid moths (Lepidoptera, Geometridae) from the territory of Buryatia. Zoolgicheskii zhurnal, 84 (3): 1433-1438. [In Russian with English Summary]

Vasilyeva, T.G. \& Epova V.I. 1987. Geometrid moths (Lepidoptera, Geometridae) of the BAM zone. P. 63-73. In: Rozhkov A.S. (Ed.) Insect of the BAM zone. Nauka, Novosibirsk. [In Russian]

Vasilyeva, T.G. 1989. To the fauna of geometrids (Lepidoptera, Geometridae) of the Southern Baikal. P. 104-115. In: Insects and arachnids of Siberia. Irkutsk, 1989. [In Russian]

Viidalepp, J. 1974. Die Eupithecia-Arten aus Sibirien in der Sammlung der Staats-Universität $\mathrm{Zu}$ Tartu (Lepidoptera, Geometridae). Tartu Riikliku Ülikooli toimetised, 327 (Zooloogiaalaseid töid, 8): 86-93. [In Russian with German Summary]

Viidalepp, J. 1975. To the fauna of moths (Lepidoptera, Geometridae) of the Mongolian People's Republic. P. 438-490. In: Emelyanov, A.F. \& Kerzhner, I.M. (Eds). Insects of Mongolia. Issue 3. Nayka, Leningrad. [In Russian]

Viidalepp, J. 1977. List of geometrid moths (Lepidoptera, Geometridae) of the fauna of USSR, 2. Entomologicheskoe obozrenie, 56 (3): 564-576. [In Russian]

Viidalepp, J. 1978. List of geometrid moths (Lepidoptera, Geometridae) of the fauna of USSR, 3. Entomologicheskoe obozrenie, 57 (4): 752-761. [In Russian]

Viidalepp J. 1979. On the fauna of Lepidoptera of Tuva ASSR. IV. Geometridae. Tartu Riikliku Ülikooli toimetised, 483 (Zooloogia-alaseid töid, 12): 79-133. [In Russian with English Summary] 
Viidalepp, J. 1987. To the fauna of moths of the Evenk Autonomous Okrug and the BAM zone. P. 74-82. In: Rozhkov A.S. (Ed.) Insect of the BAM zone. Nauka, Novosibirsk. [In Russian]

Viidalepp, J. 1996. Checklist of the Geometridae (Lepidoptera) of the former U.S.S.R. Apollo Books, Stenstrup. 1996. P. 1-111.

Wehrli, E. 1939-1954. Subfamilie: Geometrinae. S. 254-722, Tafl. 19-53. In: Seitz A. (Ed.). Die Gross-Schmetterlinge der Erde. Die Spannerartigen Nachtfalter. Bd. 4 (Supplement). Verlag A. Kernen, Stuttgart.

Zolotuhin, V.V. 2017. A new species from the Lower Volga and Caucasus and taxonomic notes on Ourapteryx Leach, 1814 (Lepidoptera: Geometridae). P 529-534. In: Anikin, V.V., Sachkov, S.A. \& Zolotuhin, V.V. "Fauna lepidopterologica Volgo-Uralensis": from P. Pallas to present day. Proceedings of the Museum Witt Munich. Vol. 7. Munich and Vilnius. 